\title{
Metals releases and disinfection byproduct formation in domestic wells following shock chlorination
}

\author{
M. Walker and J. Newman \\ University of Nevada, Department of Natural Resources and Environmental Science, MS 370/FA 132, \\ 1664 N. Virginia Street, Reno, NV 89557, USA
}

Received: 11 May 2010 - Published in Drink. Water Eng. Sci. Discuss.: 4 June 2010

Revised: 23 November 2010 - Accepted: 28 November 2010 - Published: 4 January 2011

\begin{abstract}
Shock chlorination is used for rapid disinfection to control pathogens and nuisance bacteria in domestic wells. A typical shock chlorination procedure involves adding sodium hypochlorite in liquid bleach solutions to achieve concentrations of free chlorine of up to $200 \mathrm{mg} \mathrm{L}^{-1}$ in the standing water of a well. The change in $\mathrm{pH}$ and oxidation potential may bring trace metals from aquifer materials into solution and chlorine may react with dissolved organic carbon to form disinfection byproducts. We carried out experiments with four wells to observe and determine the persistence of increased concentrations of metals and disinfection byproducts. Water samples from shock chlorinated wells were analyzed for $\mathrm{Pb}, \mathrm{Cu}, \mathrm{As}$, radionuclides and disinfection byproducts (haloacetic acids and trihalomethanes), immediately prior to treatment, after sufficient treatment time with chlorine had elapsed, and at intervals determined by the number of casing volumes purged, for up to four times the well casing volume.

Elevated concentrations of lead and copper dissipated in proportion to free chlorine (measured semiquantitatively) during the purging process. Trihalomethanes and haloacetic acids were formed in wells during disinfection. In one of two wells tested, disinfection byproducts dissipated in proportion to free chlorine during purging. However, one well retained disinfection byproducts and free chlorine after $4 \mathrm{WV}$ had been purged. Although metals returned to background concentrations in this well, disinfection byproducts remained elevated, though below the MCL. This may have been due to well construction characteristics and interactions with aquifer materials. Simple chlorine test strips may be a useful method for indicating when purging is adequate to remove metals and disinfection by-products mobilized and formed by shock chlorination.
\end{abstract}

\section{Introduction}

Shock chlorination is an in-situ method for disinfecting water wells contaminated with pathogens and nuisance bacteria. Much guidance is available for treatment of domestic wells (e.g. Schnieders, 2005; Driscoll, 1986) and http://www. unce.unr.edu/publications/files/nr/2006/FS0668.pdf, last accessed April 2010). The guidelines recommend CT values (free chlorine concentrations $\times$ resting time of the solution) that are very high relative to those used for public water supply treatment, which is appropriate given that treatments occur sporadically, usually in response to perceived problems with water or the health of those who consume water from a well. The procedure typically involves

Correspondence to: $\mathrm{M}$. Walker

(mwalker@cabnr.unr.edu) adding sodium hypochlorite solution directly to a well followed by mixing and a resting period of $12-24 \mathrm{~h}$. The chlorinated water must be purged prior to resuming use. Recommendations for the amount of purging vary significantly, with Schnieders (2005) recommending 10-20 well volumes, and University of Ohio Cooperative Extension and others recommending purging until water no longer smells of chlorine (http://ohioline.osu.edu/aex-fact/0318.html, http: //srwqis.tamu.edu/media/2553/shockwells.pdf, last accessed April 2010). Cooperative Extension is part of the landgrant system of universities throughout the United States. In most states, Cooperative Extension maintains offices in each county seat in a state. Specialists and educators based in each county provide advice and information on a wide range of topics, including management and treatment of private domestic water supplies. 
Table 1. Well characteristics and water physical and chemical characteristics immediately prior to shock chlorination; DTW is depth to water from the land surface, WD is total depth of the well, Static vol. refers to the standing volume of water in a well after water level recovery following the end of pumping. The measurements reported are also referred to as IP (Initial Purge) in Table 4. Initial Purge refers to purging prior to treatment, to replace water stored in the casing with water from the surrounding saturated formations. Well diameter, case material, depth to water from the land surface and well depth were recorded at each site. The screened interval length was obtained from well logs available on the Nevada Division of Water Resources (http://water.nv.gov/, last accessed April 2010).

\begin{tabular}{|c|c|c|c|c|c|c|}
\hline $\begin{array}{l}\text { US fish and wildlife } \\
\text { service site designation } \\
\text { (year finished) }\end{array}$ & $\begin{array}{l}\text { Well dia } \\
\mathrm{cm} \text { (in) }\end{array}$ & $\begin{array}{c}\text { Case } \\
\text { material }\end{array}$ & $\begin{array}{l}\text { DTW from } \\
\text { land surface } \\
\text { m (ft) }\end{array}$ & $\begin{array}{l}\text { WD from } \\
\text { land surface } \\
\text { m (ft) }\end{array}$ & $\begin{array}{l}\text { Screened interval } \\
\text { length } \\
\mathrm{m}(\mathrm{ft})\end{array}$ & $\begin{array}{l}\text { Static vol. } \\
\qquad 1 \text { (gal) }\end{array}$ \\
\hline $182(1975)$ & $15(6)$ & PVC & $3.4(11.1)$ & $9.4(31.0)$ & $4.6-7.9(15.0-26.0)$ & $110.6(29.2)$ \\
\hline $167 N(1996)$ & $15(6)$ & Steel & $2.4(8.0)$ & $9.0(29.6)$ & $8.2-9.1(27.0-30.0)$ & $120.0(31.7)$ \\
\hline $51(1994)$ & $15(6)$ & Steel & $1.7(5.5)$ & $20.4(67)$ & $18.9-20.4(62.0-67.0)$ & $171.2(45.2)$ \\
\hline $142(1993)$ & $15(6)$ & Steel & $3.6(11.8)$ & $8.1(26.7)$ & $6.4-7.9(21.0-26.0)$ & $84.8(22.4)$ \\
\hline \multirow{2}{*}{$\begin{array}{l}\text { US fish and wildlife } \\
\text { service site designation }\end{array}$} & \multirow[t]{2}{*}{$\mathrm{pH}$} & Temperature & Conductivity & Oxidation-reduction & Bleach added & Treatment \\
\hline & & ${ }^{\circ} \mathrm{C}$ & $\mathrm{mS} \mathrm{cm}^{-1}$ & $\mathrm{mV}$ & 1 (gal) & (h) \\
\hline 182 & 8.50 & 14.9 & 0.740 & not taken & $1.0(0.3)$ & $20 \mathrm{~h}$ \\
\hline $167 \mathrm{~N}$ & 7.14 & 16.9 & 0.345 & 114 & $1.1(0.3)$ & $15 \mathrm{~h}$ \\
\hline 51 & 7.27 & 15.57 & 0.454 & 270 & $1.5(0.4)$ & $24 \mathrm{~h}$ \\
\hline 142 & 7.67 & 16.86 & 2.093 & -123 & $0.7(0.2)$ & $17 \mathrm{~h}$ \\
\hline
\end{tabular}

The odor threshold for chlorine gas in air is approximately $0.3 \mathrm{mg} \mathrm{L}^{-1}$ (Amoore and Hautala, 1983). The relationship between the amount of chlorine degassing from a solution and the amount that can be detected by smell varies, depending upon the individual sensitivity and the degassing rate, which is in turn related to mixing dynamics within a water body, contact time, temperature of water, and changes in temperature and barometric pressure. Because of these several factors, guidelines about purging based on scent are subjective and the consistency and efficacy of application may vary considerably between people.

Aqueous chlorine (as hypochlorite ion and hypochlorous acid) cleaves carbon-carbon bonds in organic molecules to form two classes disinfection byproducts (DBPs), haloacetic acids (HAAs) and trihalomethanes (THMs) (Westerhoff et al., 2004). HAAs and THMs include carcinogenic organic compounds and have Maximum Contaminant Levels (MCLs) of $0.060 \mathrm{mg} \mathrm{L}^{-1}$ for HAA5 (the sum of concentrations of monochloroacetic acid, dichloroacetic acid, trichloroacetic acid, monobromoacetic acid and dibromoacetic acid) and $0.080 \mathrm{mg} \mathrm{L}^{-1}$ for total THM, as specified in the Stage 1 Disinfectants/Disinfection Byproducts Rule (40 CFR, Parts 9, 141 and 142) (http://water. epa.gov/drink/contaminants/index.cfm\#Byproducts, last accessed August 2010). Trihalomethanes include chloroform, bromodichloromethane, dibromochloromethane, and bromoform.

Shock chlorination may also increase the concentrations of lead and other trace elements following treatment (Seiler, 2006) and change arsenic concentrations (Gotkowitz et al.,
2008). Both lead and arsenic have toxicological effects, with an Action Level and Maximum Contaminant Level of $<15 \mu \mathrm{g} \mathrm{L}^{-1}$ and $10 \mu \mathrm{gL}^{-1}$, respectively.

This paper describes the changes in concentration of $\mathrm{Pb}$, $\mathrm{Cu}, \mathrm{As}, \mathrm{U}$, gross- $\alpha$ and gross- $\beta$ radiation, HAA5, THM, and free chlorine (semi-quantitatively measured) from shock chlorination of four domestic water wells. The study also sought to demonstrate that simple test strips for semiquantitative measurement of concentration of free chlorine (used for pool and spa maintenance) indicates when purging has returned concentrations of metals and disinfection byproducts to pre-treatment background levels. Test strips may be a better indicator than the scent of water that posttreatment purging is complete, because they provide a semiquantitative indicator of total chlorine concentrations.

\section{Methods and materials}

\subsection{Study site}

Four wells (Table 1) were selected in the Lahontan Valley, in Nevada (Fig. 1). Each well was used for domestic supply prior to being retired for water right acquisition by the US Fish and Wildlife Service within the Stillwater National Wildlife Refuge. Three were cased with steel (ASTM A135 SCH40 ERW low-carbon steel, based on inspections at the sites) and one was cased with polyvinyl chloride casing (specifications unknown). These wells were chosen for two reasons. First, they conformed to standards and practices commonly used for domestic water well 


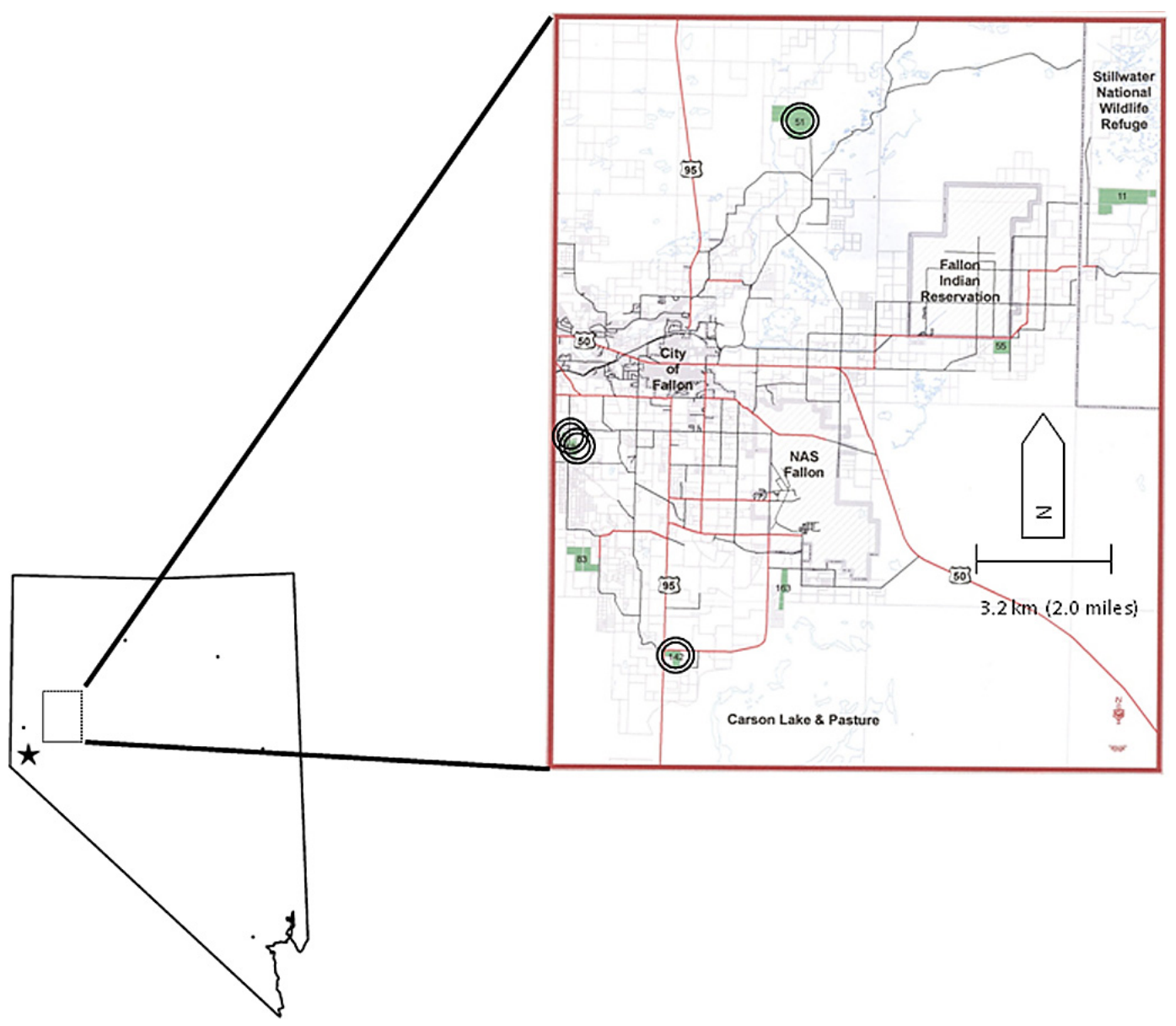

Figure 1. Location of study area, with locations of test wells indicated in circles.

construction and had well logs available through the Nevada State Engineer's office. Second, because they were no longer in service we did not run the risk of exposing people to metals or disinfection by-products released or created by shock chlorination. Well logs for each indicated that the exteriors of screened intervals on the casing were packed with gravel for wells 182 (PVC-cased), 167N (steel-cased) and 142 (steel-cased). The construction $\log$ for well 51 (steel-cased) contained incomplete information about how the screened interval was finished. The wells pumped water from a stratum of Quaternary valley-fill sands in the inland terminus of the Carson River from depths of less than $15 \mathrm{~m}(50 \mathrm{ft})$ from the land surface. Infiltration from irrigation and the Carson River has been identified as the main source of recharge (Glancy, 1986). Although the groundwater system in the Lahontan Valley is nominally comprised of three geochemically separated systems (shallow $(<15.2 \mathrm{~m}$ $(50 \mathrm{ft})$ from the land surface); intermediate $(15.2-<152.4 \mathrm{~m}$ $(50-<152.4 \mathrm{ft})$; deep $(\geq 152.4 \mathrm{~m}(\geq 500 \mathrm{ft}))$, aquifer material composition, yields and chemistry vary highly throughout the region (Glancy, 1986). Water in the aquifer has high but spatially variable concentrations of arsenic (as much as $2100 \mathrm{mg} \mathrm{L}^{-1}$ (Walker et al., 2005)) and uranium (as much as $290 \mathrm{mg} \mathrm{L}^{-1}$ (http://www.atsdr.cdc.gov/HAC/PHA/ fallonleukemia2/fln_p1.html, last accessed April 2010) from contact with sediments and from long-term evapoconcentration (Welch and Lico, 1998). Depth to water (DTW) in the four wells ranged from 1.7 to $5.5 \mathrm{~m}$ (5.5 to $18.0 \mathrm{ft}$ ) with total well depth ranging from 8.0 to $9.5 \mathrm{~m}$ (26.7 to $31.0 \mathrm{ft}$ ) (Table 1).

\subsection{Well treatment and purging}

A $1 / 2$ horsepower portable jet pump fitted with a $7.6 \mathrm{~m}(25 \mathrm{ft})$ long, $1.9 \mathrm{~cm}$ ( $0.75 \mathrm{in})$ interior diameter suction line was used for each trial. The pump and suction line were rinsed with distilled, deionized water between uses and allowed to air dry. Each well was chlorinated and purged as a separate experiment, to avoid cross-contamination of wells. The pump had a fiberglass-reinforced thermoplastic housing and impeller, with Buna-N seals and ceramic bearings. The outflow line was fitted with a GPI electronic inline flow meter, a flow control valve, and a tee that divided flow between a discharge hose and a flow-through chamber for 
Table 2. Sampling intervals used, with associated chemical constituents measured.

\begin{tabular}{|c|c|c|c|c|}
\hline Sample type & $\begin{array}{l}\text { Initial Purge } \\
\text { (IP) }\end{array}$ & $\begin{array}{l}\text { Post-Chlorination } \\
\text { (PC) }\end{array}$ & $\begin{array}{l}\text { Post-Chlorination Purging } \\
\text { (PCP, for } 1 / 2,1,2, \\
\text { and } 3 \text { well volumes) }\end{array}$ & $\begin{array}{c}\text { Final } \\
(4 \mathrm{~F}: 4 \text { well } \\
\text { volumes purged })\end{array}$ \\
\hline gross $\alpha$, gross $\beta$, Uranium & $\sqrt{ }$ & $\sqrt{ }$ & & $\sqrt{ }$ \\
\hline Metals $(\mathrm{Cu}, \mathrm{Pb}, \mathrm{As})$ & $\sqrt{ }$ & $\sqrt{ }$ & $\sqrt{ }$ & $\sqrt{ }$ \\
\hline HAA5, THM (wells 142 and 182) & $\sqrt{ }$ & $\sqrt{ }$ & & $\sqrt{ }$ \\
\hline Total Organic Carbon (wells 142 and 182) & $\sqrt{ }$ & & & \\
\hline Chlorine Test Strips & & $\sqrt{ }$ & $\sqrt{ }$ & $\sqrt{ }$ \\
\hline
\end{tabular}

a YSI model 556MPS (Yellow Springs Instruments, Yellow Springs $\mathrm{OH}$ ), for real-time measurement of temperature $\left(T\left({ }^{\circ} \mathrm{C}\right)\right), \mathrm{pH}$, oxidation-reduction potential $(\mathrm{ORP}(\mathrm{mV}))$, and conductivity $\left(\mathrm{C}\left(\mathrm{mS} \mathrm{cm}^{-1}\right)\right)$. The multi-probe was calibrated immediately prior to each stage of field trials, using pH 4.00, 7.00 and 10.00 standards (Fisher Scientific BufferPac, Cat\# SB105), a conductivity standard $\left(1000 \mathrm{mS} \mathrm{cm}^{-1}\right.$ at $25^{\circ} \mathrm{C}$ (Yellow Springs Instrument Co. Cat \#3167) and an oxidation-reduction potential reference solution (Equipco Inc., part \#3682500).

Prior to conducting trials, each well was purged of stagnant water at a rate of 9.5 to 18.9 liters per minute ( 2.5 to $5.0 \mathrm{gpm}$ ) until temperature, $\mathrm{pH}$, ORP, and conductivity readings stabilized ( $<5 \%$ variation in continuous readings), then purged an additional four times the well's standing volume of water. The standing well volume (WV) was estimated as $\mathrm{WV}=H \times A$, with $H$ as the measured height of the water column in the well after the level stabilized following pumping and $A$ as the cross sectional area of the interior of the well casing. Using this as a basis for purging following treatment differs from the dynamic well volume, which represents the steady state water level achieved during pumping. This differs from the static water level due to drawdown during pumping. The water levels used as a reference in this paper are standing well volumes (WV), which do not reflect the influence of pumping. Pre-chlorination (designated as IP) water samples for all wells were collected for $\mathrm{As}, \mathrm{Cu}, \mathrm{Pb}, \mathrm{U}$, gross- $\alpha$ and gross- $\beta$ radiation, total organic carbon, and for a steel-cased well and a PVC-cased well, water samples were collected for HAA5 and THM analyses. Table 1 presents IP conditions in each well.

\subsection{Shock chlorination}

Following initial purging, each well was chlorinated to an estimated $200 \mathrm{mg} \mathrm{L}^{-1}$ as total $\mathrm{Cl}$ using household bleach (unscented, regular strength Clorox ${ }^{\circledR}$ labeled as containing $6 \%$ sodium hypochlorite $(\mathrm{NaOCl})$, which is $64.6 \% \mathrm{Cl}$ by mass) by adding $8.9 \mathrm{ml}(0.3 \mathrm{fl} \mathrm{oz})$ bleach per liter $(0.26$ gallons $)$ of well volume (Table 1). Pump discharge was circulated back into the well casing for $15 \mathrm{~min}$ to disperse bleach into solu-
Table 3. Methods used for sample analysis. "EPA" refers to a standard analytic method published by the US Environmental Protection Agency (available at http://www.epa.gov/sam/index.htm, last accessed April 2010), used by the Nevada State Health Laboratory. "SM" refers to standard method $5310 \mathrm{C}$ (Persulfate-ultraviolet or Heated Persulfate Oxidation Method), published in Standard Methods for the Examination of Examination of Water and Wastewater (Clesceri et al., 1998). Total Organic Carbon samples were analyzed using a Shimadzu Spectrophotometer at the University of Nevada.

\begin{tabular}{lll}
\hline Analyte & Method & $\begin{array}{l}\text { Analytic detection } \\
\text { limits }\left(\mathrm{mg} \mathrm{L}^{-1}\right)\end{array}$ \\
\hline Copper & EPA 200.7 & $0.020,0.050$ \\
Arsenic, Lead, Uranium & EPA 200.8 & $0.003,0.002,0.002$ \\
gross $\alpha$, gross $\beta$ & EPA 900.0 & $3 \mathrm{pCi} \mathrm{L}^{-1}$ \\
THM & EPA 524.2 & 0.005 \\
HAA5 & SM 6251B & 0.001 \\
TOC & SM 5310C & $1.0^{*}$ \\
\hline
\end{tabular}

* The analytic detection limit is based on linear regression analysis of the calibration curve, conducted with three replicates each of 4 standards, ranging from 0.274 $20.270 \mathrm{mg} \mathrm{L}^{-1}$.

tion. Wells were re-capped for a resting period of at least twelve hours.

\subsection{Sampling}

Immediately prior to and during purging temperature, $\mathrm{pH}$, oxidation-reduction potential, and conductivity were measured. Immediately prior to purging post-chlorination (PC) samples from all wells were tested for $\mathrm{As}, \mathrm{Cu}, \mathrm{Pb}, \mathrm{U}$, and gross- $\alpha$ and gross $-\beta$ radiation. Samples from two wells (142 and 182) were tested for disinfection byproducts (HAA5 and THM). All metals and disinfection by-products samples were collected using a PTFE dip bailer.

Post chlorination purging samples were collected for As, $\mathrm{Cu}$, and $\mathrm{Pb}$ at intervals defined by the volume of water purged from each well, including $1 / 2,1,2,3$, and $4 \times \mathrm{WV}$ (designated as $1 / 2,1,2,3,4)$. After $4 \mathrm{WV}$, samples were collected for As, $\mathrm{Cu}, \mathrm{Pb}, \mathrm{U}$, gross- $\alpha$ and gross $-\beta$ radiation, HAA5 and THM (Table 2). 
Table 4. Physical and chemical characteristics of water in test wells observed during post-chlorination purging ( $T$ : temperature, $C$ : conductivity, ORP: oxidation-reduction potential, ND: not measured). Final column displays the percentage difference between values at IP (prior to chlorination) and post-chlorination, with 4 well volumes purged.

\begin{tabular}{lccccccc}
\hline Well volumes purged $\rightarrow$ & 0 & $1 / 2$ & 1 & 2 & 3 & 4 & $(\mathrm{IP}-4) / \mathrm{IP} \%$ \\
\hline $182($ discharge rate $=14.4$ liters & per minute & $(3.8 \mathrm{gpm}))$ \\
\hline$T\left({ }^{\circ} \mathrm{C}\right)$ & 16.7 & 15.7 & 15.7 & 15.7 & 15.6 & 15.7 & $5 \%$ \\
$C\left(\mathrm{mS} \mathrm{cm}{ }^{-1}\right)$ & 0.68 & 0.49 & 0.56 & 0.56 & 0.54 & 0.55 & $-26 \%$ \\
$\mathrm{pH}$ & 7.97 & 7.57 & 7.70 & 7.52 & 7.47 & 7.58 & $-11 \%$ \\
$\mathrm{ORP}(\mathrm{mV})$ & 772 & 817 & 810 & 827 & 837 & 828 & no IP \\
\hline $167 \mathrm{~N}($ discharge rate $=18.9$ liters & per minute $(5.0 \mathrm{gpm}))$ \\
\hline$T\left({ }^{\circ} \mathrm{C}\right)$ & $\mathrm{ND}$ & 17.1 & 17.1 & 17.1 & 17.1 & 17.1 & $1 \%$ \\
$C\left(\mathrm{mS} \mathrm{cm}{ }^{-1}\right)$ & 2.12 & 1.23 & 0.53 & 0.45 & 0.42 & 0.44 & $27 \%$ \\
$\mathrm{pH}$ & 8.78 & 8.38 & 7.82 & 7.56 & 7.27 & 7.51 & $5 \%$ \\
$\mathrm{ORP}(\mathrm{mV})$ & 732 & 787 & 793 & 783 & 791 & 777 & $581 \%$ \\
\hline $51($ discharge rate $=14.6$ liters per minute $(3.9 \mathrm{gpm}))$ & & & \\
\hline$T\left({ }^{\circ} \mathrm{C}\right)$ & 16.4 & 14.8 & 15.0 & 15.1 & 15.3 & 15.2 & $-3 \%$ \\
$C\left(\mathrm{mS} \mathrm{cm}{ }^{-1}\right)$ & 1.95 & 1.07 & 1.08 & 0.79 & 0.81 & 0.77 & $70 \%$ \\
$\mathrm{pH}$ & 8.65 & 8.8 & 8.5 & 8.27 & 8.41 & 8.42 & $16 \%$ \\
$\mathrm{ORP}(\mathrm{mV})$ & 867 & 957 & 962 & 956 & 831 & 586 & $117 \%$ \\
\hline $142($ discharge rate $=2.5$ liters per minute $(0.7 \mathrm{gpm}))$ & & & \\
\hline$T\left({ }^{\circ} \mathrm{C}\right)$ & 22.4 & 16.7 & 16.7 & 16.6 & 16.6 & 16.6 & $-2 \%$ \\
$C\left(\mathrm{mS} \mathrm{cm}{ }^{-1}\right)$ & 2.26 & 1.64 & 2.07 & 2.04 & 1.97 & 1.94 & $-7 \%$ \\
$\mathrm{pH}$ & 8.56 & 8.48 & 8.13 & 7.71 & 7.74 & 7.73 & $1 \%$ \\
$\mathrm{ORP}(\mathrm{mV})$ & 704 & 719 & 719 & -109 & -124 & -124 & $1 \%$ \\
\hline
\end{tabular}

All samples were unfiltered. Samples were collected, immediately placed in a portable cooler with blue ice to avoid exposure to sunlight and changes in temperature and submitted within $24 \mathrm{~h}$ to the Nevada State Health Laboratory (University of Nevada School of Medicine, Reno, NV - a certified drinking water analysis laboratory) for analysis (Table 3). Samples for arsenic, copper, lead and uranium were collected in $500 \mathrm{ml}$ high density polyethylene bottles with $5.0 \mathrm{ml}$ of $15 \%$ nitric acid as a preservative in containers provided by the laboratory. After sample collection, the final concentration of nitric acid was $0.15 \%$ nitric acid.

\subsection{Chlorine test strips}

Free chlorine was measured semi-quantitatively with test strips for swimming pool and spa maintenance (Arch Chemicals, Inc. - HTH line). The test strips indicated free chlorine concentrations in ranges rather than absolute numbers, similar to $\mathrm{pH}$ indicator strips. In order to determine the range, a user dips the strip in a solution and compares colors appearing in segregated rectangles with a key. The ranges reported include undetectable (indicated as 0 on the test strip), $>0-1 \mathrm{mg} \mathrm{L}^{-1},>1-2 \mathrm{mg} \mathrm{L}^{-1},>2-3 \mathrm{mg} \mathrm{L}^{-1},>3-$ $5 \mathrm{mg} \mathrm{L}^{-1},>5-10 \mathrm{mg} \mathrm{L}^{-1}$ and $>10 \mathrm{mg} \mathrm{L}^{-1}$. We tested the ac- curacy of the strips using dilutions of sodium hypochlorite solution and determined that they were adequate for distinguishing between the classes noted above (data not shown).

\section{Results and discussion}

\subsection{Conductivity, $\mathrm{pH}$, oxidation-reduction potential and temperature}

Post-chlorination conductivity measurements were elevated from initial values, and returned to near initial values following purging $4 \mathrm{WV}$ (Table 4). $\mathrm{pH}$ rose in wells $167 \mathrm{~N}$ and 51 and decreased slightly in wells 182 and 42 . Increases in $\mathrm{pH}$ conform to observations that concentrations of chlorine of $200 \mathrm{mg} \mathrm{L}^{-1}$ can be expected to increase $\mathrm{pH}$ by up to two units (Schnieders, 2005). Oxidation-reduction potential increased above pre-chlorination levels in all wells, as would be expected with the addition of an oxidizer. Water in well 142 returned to background levels for temperature, $\mathrm{pH}$, conductivity, and oxidation-reduction potential after four WV had been purged, though measurements from the other wells indicated that $4 \mathrm{WV}$ of purging was not sufficient to return to background conditions (Table 4). The oxidation-reduction potential in wells 51 and 167 remained above background 
Table 5. Trace metal concentrations from pre-treatment (PT) through purging, expressed in number of well volumes pumped. The Maximum Contaminant Level for arsenic is $0.010 \mathrm{mg} \mathrm{L}^{-1}$. Action Levels for lead and copper are 1.3 and $0.015 \mathrm{mg} \mathrm{L}^{-1}$, respectively. Samples that contained analytes in concentrations less than the reporting limit (RL) are reported as " $<$ RL." The reporting limit for lead varied according to results of internal laboratory quality control assessments and chemical quality of water samples.

\begin{tabular}{|c|c|c|c|c|c|c|c|}
\hline \multirow[b]{2}{*}{ Metals $\left(\mathrm{mg} \mathrm{L}^{-1}\right)$} & \multicolumn{7}{|c|}{ Well volumes purged } \\
\hline & PT & 0 & $1 / 2$ & 1 & 2 & 3 & 4 \\
\hline \multicolumn{8}{|l|}{182} \\
\hline Arsenic & 0.020 & 0.016 & 0.016 & 0.020 & 0.021 & 0.021 & 0.021 \\
\hline Copper & $<0.02$ & 0.04 & $<0.02$ & $<0.02$ & $<0.02$ & $<0.02$ & $<0.02$ \\
\hline Lead & $<0.001$ & 0.011 & 0.001 & $<0.001$ & $<0.001$ & $<0.001$ & $<0.001$ \\
\hline $\mathrm{Cl}$ & $<1$ & $>10$ & $>10$ & $>10$ & $>10$ & $>10$ & $>3-5$ \\
\hline \multicolumn{8}{|l|}{$167 \mathrm{~N}$} \\
\hline Arsenic & 0.019 & 0.024 & 0.018 & 0.019 & 0.019 & 0.019 & 0.019 \\
\hline Copper & $<0.02$ & 0.03 & 0.04 & $<0.02$ & $<0.02$ & $<0.02$ & $<0.02$ \\
\hline Lead & $<0.001$ & 0.013 & 0.008 & $<0.002$ & $<0.001$ & $<0.001$ & $<0.001$ \\
\hline $\mathrm{Cl}$ & $<1$ & $>10$ & $>10$ & $>10$ & $>3-5$ & $>2-3$ & $>1-2$ \\
\hline \multicolumn{8}{|l|}{142} \\
\hline Arsenic & 0.580 & 0.440 & 0.460 & 0.750 & 0.620 & 0.590 & 0.600 \\
\hline Copper & $<0.02$ & $<0.02$ & 0.02 & $<0.02$ & $<0.02$ & $<0.02$ & 0.02 \\
\hline Lead & $<0.010$ & 0.010 & $<0.010$ & $<0.010$ & $<0.010$ & $<0.010$ & 0.010 \\
\hline $\mathrm{Cl}$ & $<1$ & $>10$ & $>10$ & $<1$ & $<1$ & $<1$ & $<1$ \\
\hline \multicolumn{8}{|l|}{51} \\
\hline Arsenic & 0.410 & 0.390 & 0.380 & 0.410 & 0.460 & 0.460 & 0.460 \\
\hline Copper & $<0.02$ & 0.08 & 0.08 & 0.06 & $<0.02$ & $<0.02$ & $<0.02$ \\
\hline Lead & 0.003 & 0.022 & 0.016 & 0.012 & 0.003 & 0.002 & 0.003 \\
\hline $\mathrm{Cl}$ & $<1$ & $>10$ & $>10$ & $>10$ & $>1-2$ & $<1$ & $<1$ \\
\hline
\end{tabular}

levels, though temperature and $\mathrm{pH}$ were $<16 \%$ of starting values. This suggests that the oxidizing effects of chlorination led to short-term changes in the immediate vicinity of the well screen or that were stagnant zones within the well, which would have required more purging to eliminate.

\subsection{Chlorine concentration}

Decreases of free chlorine concentration were hypothesized to be an indicator of purging of mobilized trace metals and disinfection byproducts. The concentration of free chlorine decreased in wells $51,167 \mathrm{~N}$ and 142 to $>1-2$ ppm free chlorine after $4 \mathrm{WV}$ were pumped (Table 5). Site 182 required that $5 \mathrm{WV}$ be purged before free chlorine decreased to $>3-$ 5 ppm (data not shown).

\subsection{Mobilization of trace metals}

Concentrations of lead and copper in well water increased following shock chlorination, which corresponds with results reported by Seiler (2006). Lead concentrations increased up to thirteen-fold and copper concentrations increased up to four-fold following treatment. Concentrations of both decreased to initial levels within $2 \mathrm{WV}$ of purging. The return to background levels corresponded with the decline in free chlorine to $>3-5 \mathrm{mg} \mathrm{L}^{-1}$ (Table 5).

All wells contained arsenic in concentrations that exceeded the MCL $\left(0.010 \mathrm{mg} \mathrm{L}^{-1}\right)$ prior to treatment. The decline in arsenic concentration in the chlorine solution prior to purging was similar to results reported by Gotkowitz et al. (2008) and would be expected with the observed changes $\mathrm{pH}$ and oxidation-reduction potential. However, the decline was followed by an increase in arsenic above background levels during pumping. After $4 \mathrm{WV}$, water from one well returned to initial arsenic concentrations, while the others remained 3-12\% higher than initial concentrations.

\subsection{Uranium and radionuclides}

Samples were analyzed for uranium and gross- $\alpha$ and gross- $\beta$ radionuclides (Table 6 ). Uranium concentrations increased at sites 51 and 142 but remained the same or decreased in wells $167 \mathrm{~N}$ and 187 . Concentrations returned to approximately the same as starting levels in all wells after purging 4 
Table 6. Uranium, gross- $\alpha$ and gross- $\beta$ results for three stages of treatment: IP (prior to chlorination), PC (post chlorination but prior to purging) and $4 \mathrm{WV}$ (after purging 4 well volumes). The Maximum Contaminant Levels for uranium, gross$\alpha$ and gross- $\beta$ are $30 \mu \mathrm{gL}^{-1}, 15 \mathrm{pCiL}^{-1}$ and $4 \mathrm{mrem} \mathrm{yr}^{-1}$, respectively, (see http://www.epa.gov/safewater/radionuclides/pdfs/ qrg_radionuclides.pdf, last accessed April 2010).

\begin{tabular}{lccc}
\hline 182 & IP & PC & $4 \mathrm{WV}$ \\
\hline Uranium, $\mu \mathrm{g} \mathrm{L}^{-1}$ & 32 & 22 & 35 \\
gross- $\alpha, \mathrm{pCi} \mathrm{L} \mathrm{L}^{-1}$ & 18 & 21 & 24 \\
gross- $\beta, \mathrm{pCi} \mathrm{L}$ & 18 & 14 & 20 \\
\hline $167 \mathrm{~N}$ & & & \\
\hline Uranium, $\mu \mathrm{g} \mathrm{L}^{-1}$ & 13 & 13 & 13 \\
gross- $\alpha, \mathrm{pCi} \mathrm{L}^{-1}$ & 8 & 15 & 12 \\
gross- $\beta, \mathrm{pCi} \mathrm{L}^{-1}$ & 19 & 17 & 19 \\
\hline 142 & & & \\
\hline Uranium, $\mu \mathrm{g} \mathrm{L}^{-1}$ & 560 & 620 & 580 \\
gross- $\alpha, \mathrm{pCi} \mathrm{L}^{-1}$ & 120 & 92 & 127 \\
gross- $\beta, \mathrm{pCi} \mathrm{L}^{-1}$ & 173 & 168 & 158 \\
\hline 51 & & & \\
\hline Uranium, $\mu \mathrm{g} \mathrm{L}^{-1}$ & 4 & 29 & 9 \\
gross- $\alpha, \mathrm{pCi} \mathrm{L}^{-1}$ & 13 & 43 & 16 \\
gross- $\beta, \mathrm{pCi} \mathrm{L}^{-1}$ & 6 & 8 & 5 \\
\hline
\end{tabular}

WV. Gross- $\alpha$ concentrations changed from the IP to PC sampling steps, increasing in wells 51 and $167 \mathrm{~N}$, decreasing in well 142 and remaining approximately the same in well 182. Gross- $\beta$ concentrations remained approximately the same in all wells at each sampling stage, with concentrations appearing to decrease slightly between the IP and 4 WV samplings. The maximum change in gross- $\beta$ concentrations was approximately $-9 \%$ in well 142 .

\subsection{Total organic carbon and disinfection byproducts}

Total organic carbon (TOC) concentrations in wells 182 and 142, collected prior to treatment, are shown in Table 7. Water from wells obtained after treatment, but prior to purging contained concentrations of THM up to ten times the MCL (Table 7). Following purging of $4 \mathrm{WV}$, concentrations in well 142 decreased to below the detection limit, indicating that the increase in concentration was temporary and could be remediated by purging $4 \mathrm{WV}$ after treatment. Well 182 retained disinfection byproducts and free chlorine, with the concentration of free chlorine (indicated by test strips) $>10 \mathrm{mg} \mathrm{L}^{-1}$ after purging $4 \mathrm{WV}$. Testing for free chlorine at the fifth well volume purged indicated a concentration of $>3-5 \mathrm{ppm}$.
Table 7. Total Organic Carbon (TOC) concentrations following initial purging of test wells (IP), and HAA5 and THM concentrations following IP, post chlorination (PC) and after 4 well volumes (WV) had been purged.

\begin{tabular}{|c|c|c|c|}
\hline Site & $\begin{array}{l}\text { TOC } \\
\text { (IP) } \\
\mathrm{mg} \mathrm{L}^{-1}\end{array}$ & $\begin{array}{c}\text { HAA5 } \\
\text { (IP,PC,4 WV) } \\
\mu \mathrm{gL}^{-1}\end{array}$ & $\begin{array}{c}\text { THM } \\
(\mathrm{IP}, \mathrm{PC}, 4 \mathrm{WV}) \\
\mu \mathrm{gL}^{-1}\end{array}$ \\
\hline 182 & 3.9 & $<1.0,101.0,128.0$ & $<0.5,43.7,70.1$ \\
\hline 142 & 15.1 & $<1.0,394.0,<1.0$ & $<0.5,747.0,<0.5$ \\
\hline
\end{tabular}

\section{Conclusions}

This study confirmed temporary mobilization and changes in concentration of trace metals from shock chlorination treatment, as previously reported by Seiler (2006) and Gotkowitz et al. (2008). It also demonstrated that disinfection byproducts can be formed and can persist beyond $3 \mathrm{WV}$ of purging. The concentration of disinfection byproducts exceeded drinking water MCLs in the two wells tested. In one well, concentrations decreased to below the detection limits for HAA5 and THM with purging. In the other, concentrations of disinfection byproducts remained elevated, with final concentrations of THM and HAA5 at highest levels after purging $4 \mathrm{WV}$. Metals, though mobilized by shock chlorination, decreased to near pre-treatment background levels after $4 \mathrm{WV}$ were purged in all wells.

The concentrations of DBP precursors and peak concentrations of HAA5 and THM differed in the two wells sampled. Although concentrations of THM and HAA5 were lower in well 182, samples collected after $4 \mathrm{WV}$ indicated that DBPs persisted. This may have been due to differences in well construction and interaction between chlorine solutions and aquifer materials. With respect to well construction, the depths of wells and depths to water from the land surface for wells 182 and 142 were similar, but lengths of screened intervals and static volumes differed (Table 1). The screened interval in well 182 spanned $3.3 \mathrm{~m}(11 \mathrm{ft})$, com-

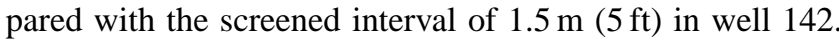
Well 182 also had approximately $1.3 \mathrm{~m}$ of casing below the screened interval, which may have served as a reservoir for residual chemicals because volume exchange in this portion of the casing would be difficult to accomplish with a surface pump. The stagnant portion of well 182 may also have contained sediments, which would have further prolonged release of HAA5 and THM into pumped water. In contrast, screens in the other wells were mounted at the bottom of the casing. Although this does not assure that complete mixing took place throughout post-treatment purging, it is more likely that purging led to complete exchanges of water within the well casing than in well 182. It is also possible that disinfection byproducts formed within the saturated formations immediately adjacent to the well screen. 
Although well logs indicated that the screened intervals were set in sands, well yields appeared to be very different based on the discharge rates used for purging and drawdowns observed. In order to maintain a steady discharge rate from well 142 , the pumping rate was $<20 \%$ of the purging rate used in well 182, even though lift distances from the water table to the surface were slightly less for well 142 than well 182. This suggests that the saturated formations in the screened intervals pumped for well 142 were less permeable than those in well 182, which in turn suggests that aquifer materials may have been composed of fine-textured soils including silts and clays. In the absence of significant advective mixing, formation of disinfection byproducts beyond the immediate well volume would be limited to chemical dispersion. In well 182, however, it is likely that a larger volume of aquifer material was exposed to chlorine. This hypothesis is, in part, supported by the persistent indication of oxidizing conditions in water withdrawn after purging $4 \mathrm{WV}$. A prior study in the region (Fram et al., 2005) demonstrated that free chlorine released significant amounts of carbon from aquifer materials. They concluded that carbon was likely released from clay minerals in proportion to the amount of available chlorine in solution. This suggests that aquifer material and interactions with high concentrations of available chlorine were a potential source of precursors to HAA5 and THM formation.

The mixing procedure used to disperse chlorine throughout the entire well volume was unlikely to have created a gradient that would advect chlorine into aquifer materials, but chemical diffusion through the well screen may have taken place during the resting phase. Given the differences in screened intervals, this may have led to accumulation of DBPS's in aquifer materials in contact with the screened interval of well 182, which could have required more thorough purging to remove than those in contact with the shorter screened interval in well 142. Although purging appeared to be adequate based on number of well volumes removed and stability of temperature and $\mathrm{pH}$, test strips indicated the presence of free chlorine. Consequently, the chemical reactions that led to metals releases and DBP formation may have been due to chemical diffusion during the resting time following introduction of bleach and likely due to reactions with aquifer materials and gravel packing in the immediate vicinity of the screened interval of the well casing.

Publications about shock chlorination recommend purging varying numbers of standing well volumes post treatment, before returning a well to service. Guidance also is based on detecting the scent of chlorine in water. Without metering equipment most domestic well owners have no accurate means of determining when pumping is sufficient to remove a specific number of well volumes. Also, determining the sufficiency of purging by scent is subjective and may not be consistent, especially with respect to avoiding exposure to metals and disinfection byproducts. The use of chlorine test strips shows promise as a simple and accurate means of de- termining when purging is complete, though this should be verified with further experimental work. This technique has the potential to be a reliable guideline for public health officials and informal educators (including county-based educators of Cooperative Extension), who provide advice about proper procedures for shock chlorination, especially when well owners cannot measure discharge rates and discharge volumes.

Acknowledgements. This material is based upon work supported by the National Institute of Food and Agriculture, US Department of Agriculture, under Agreement No. 2009-5113006048. Any opinions, findings, conclusions, or recommendations expressed in this publication are those of the author(s) and do not necessarily reflect the view of the US Department of Agriculture.

Edited by: J. Verberk

\section{References}

Amoore, J. E. and Hautala, E.: Odor as an ald to chemical safety: Odor thresholds compared with threshold limit values and volatilities for 214 industrial chemicals in air and water dilution, J. Appl. Toxicol., 3(6), 272-290, 1983.

Clesceri, L., Greenberg, A., and Eaton, A. (Eds): Standard Methods for Examination of Water and Wastewater. American Public Health Association, Washington, D.C., 1325 pp., 1999.

Driscoll, F. G.: Groundwater and Wells, 2nd ed., Johnson Division, St. Paul, MN, 1108 pp., 1986.

Fram, M. S., Maurer, D. K., and Lico, M. S.: Potential for formation of disinfection by-products from storage of chlorinated surface water in the basalt aquifer near Fallon, Nevada, US Geological Survey, Carson City, NV, 23 pp., 2005.

Glancy, P.: Geohydrology of the Basalt and Unconsolidated Sedimentary Aquifers in the Fallon Area, Churchill County, Nevada, Institution, Alexandria, Va., US Geological Survey Water Supply Paper 2263, 60 pp., 1986.

Gotkowitz, M., Ellickson, K., Clary, A., Bowman, G., Standridge, J., and Sonzogni, W.: Effect of well disinfection on arsenic in ground water, Ground Water Monit. R., 28(2), 60-67, 2008.

Schnieders, J. H.: Use of Chlorine to Disinfect Water Wells, Water Well Journal, 7, 52-53, 2005.

Seiler, R. L.: Mobilization of lead and other trace elements following shock chlorination of wells, Sci. Total Environ., 367(2-3), 757-768, 2006.

Walker, M. J., Benson, M., and Shaw, W. D.: Significance of private water supply wells as a route of exposure to aqueous arsenic, J. Water Health, 3(3), 305-312, 2005.

Welch, A. H. and Lico, M. S.: Factors controlling As and U in shallow ground water, southern Carson Desert, Nevada, Appl. Geochem., 13(4), 521-539, 1998.

Westerhoff, P., Chao, P., and Mash, H.: Reactivity of natural organic matter with aqueous chlorine and bromine, Water Res., 38(6), 1502-1513, 2004. 